\title{
Modeling Sintering Process of Iron Ore
}

\author{
Jose Adilson de Castro \\ Graduate Program on Metallurgical \\ Engineering -Federal Fluminense University \\ Brazil
}

\section{Introduction}

In this chapter, a methodology for simulating the sintering process of iron ore is presented. In order to study the process parameters and inner phenomena, a mathematical model based on transport equations of momentum energy and chemical species is proposed and the numerical implementations is discussed. The model is applied to simulate the impact of new technologies based on alternative sources of fuels, new operational design and the environmental concerns related to the new raw materials is estimated. The model is validated with pot test experiments and applied to industrial scale of sinter strand machine.

In the integrated steel industries the sintering process plays an important role furnishing raw material to the blast furnace. From the point of view of natural resources, the sintering process is key technology that allows recycling by products or dust produced within the steel plant and other facilities. However, the amount and quality of energy requirements have continuously changed and up to date is mainly based on nonrenewable energies resources such as coal, anthracite and oil. Several attempts to use new energy resources have been carried out and new technologies are continuously developed. The process is complex involving various physical and chemical phenomena. The raw materials used can vary to a wide extent, from iron ore to dust recycling and fluxing agents. The natural resources of iron ores varies widely depending on the mineral composition and mining technology applied to produce the sinter feed. Therefore, it is of special importance to developed comprehensive tools to draw good decision on what kind of available raw materials and their blending will meet the sinter quality requirements to use in the blast furnace or other reducing process(Castro et. al., 2000, 2011). The process is carried out on a moving strand, where a previously prepared mixture of iron ore (sinter feed), fine coke or anthracite(fuel), limestone, other additives and water is continuously charged together with returned sinter from the undersize of a sieving process to form a thick bed of approximately 800 millimeters. The strand width and length depends on the capacity of the machine and varies for each steel works. Along the first meters of the strand the charge is ignited by burners of natural gas or coke oven gas. The hot gas, generated by the combustion with air, is then sucked in through the packed bed from the wind boxes equipped with blowers placed below the grate. The strand can vary from small to large machines with the area and bed height compatible with the auxiliary equipments used for suction of the outlet gas. The area of the strand and the suction power together with the bed permeability determines the maximum speed and hence, the productivity of the process. However, depending on the 
selected operational parameters and raw materials the quality of the sinter produced can vary widely and can strongly effects the subsequent blast furnace process operation. The combustion of fines coke or other carbonaceous materials begins at the top of the layers, and as it moves, a relative narrow band of combustion front moves down through the bed. Several chemical reactions and phase transformations take place within the bed, part of the materials melt when the local temperature reaches the melting temperature and as it moves, the re-solidification phenomenon and phase transformations occur with considerable changes on phases composition and thermo physical properties (Jeon et al. 2010, Li et al. 2010, Nakano, 2005, 2010, Kasai, 2005, 2010, akiyama et al. 1993).

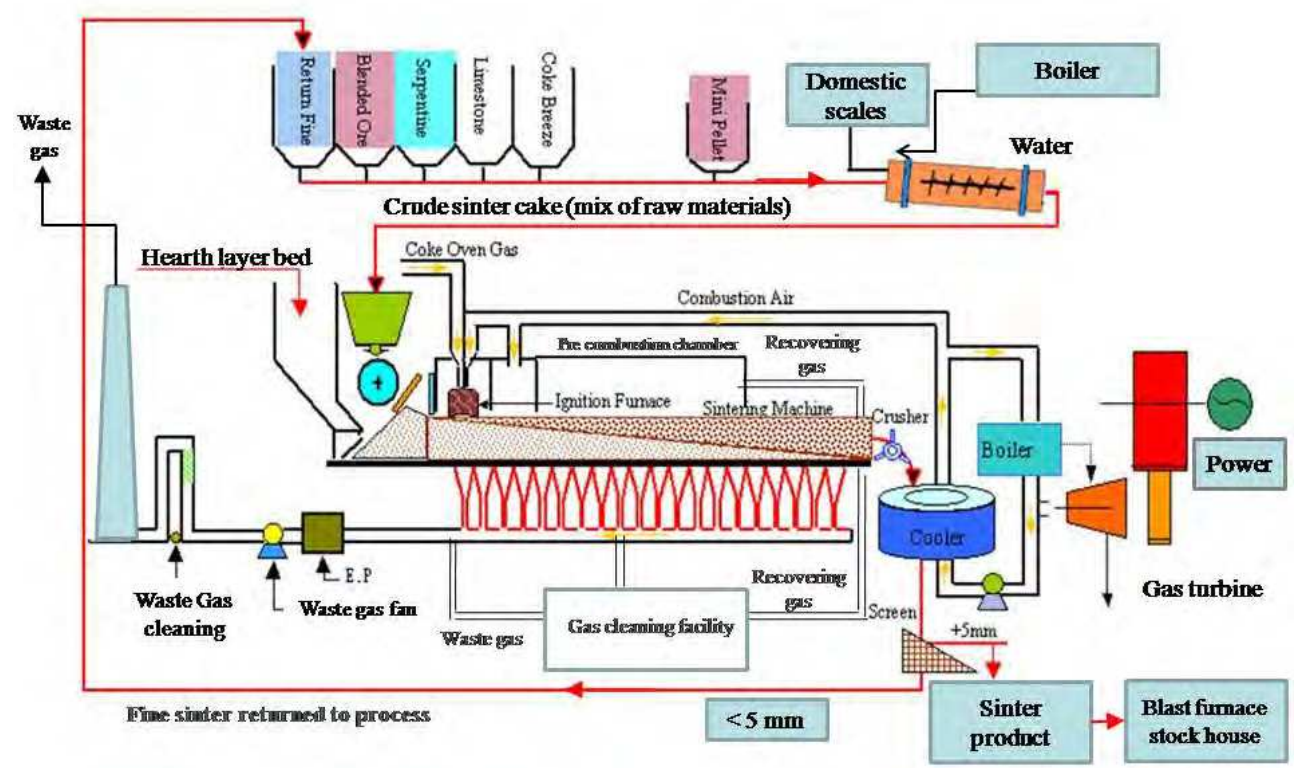

Fig. 1. Schematic overview of the sinter facilities of an integrated steel works with new facilities proposed for recycling waste gas.

The partial melting and diffusion within the materials causes the particle to agglomerate forming a continuous porous sinter cake. In general, the hot gas produced during sintering can also be re-circulated for better thermal efficiency. A schematic overview of the sinter machine with recycling gas concept is shown in Fig. 1. In addition, in this machine concept, part of the process gas is reutilized in a pre-combustion chamber with natural gas with ignition burners to keep heat supplying on the surface of the sinter strand and enlarge the heat affected zone. The physicochemical and thermal phenomena involved in this process are complex and numerous( Nakano et al, 2010, Kamijo et al. 2009, Kasai et al. 2008, 2005). Special mention is made to the phenomena of gas flow through the porous bed, gas-solid heat transfer, drying, vaporization and several chemical reactions and phase transformations (Umekage et al. 2009, Cieplik, 2003, Cores et al. 2010). 


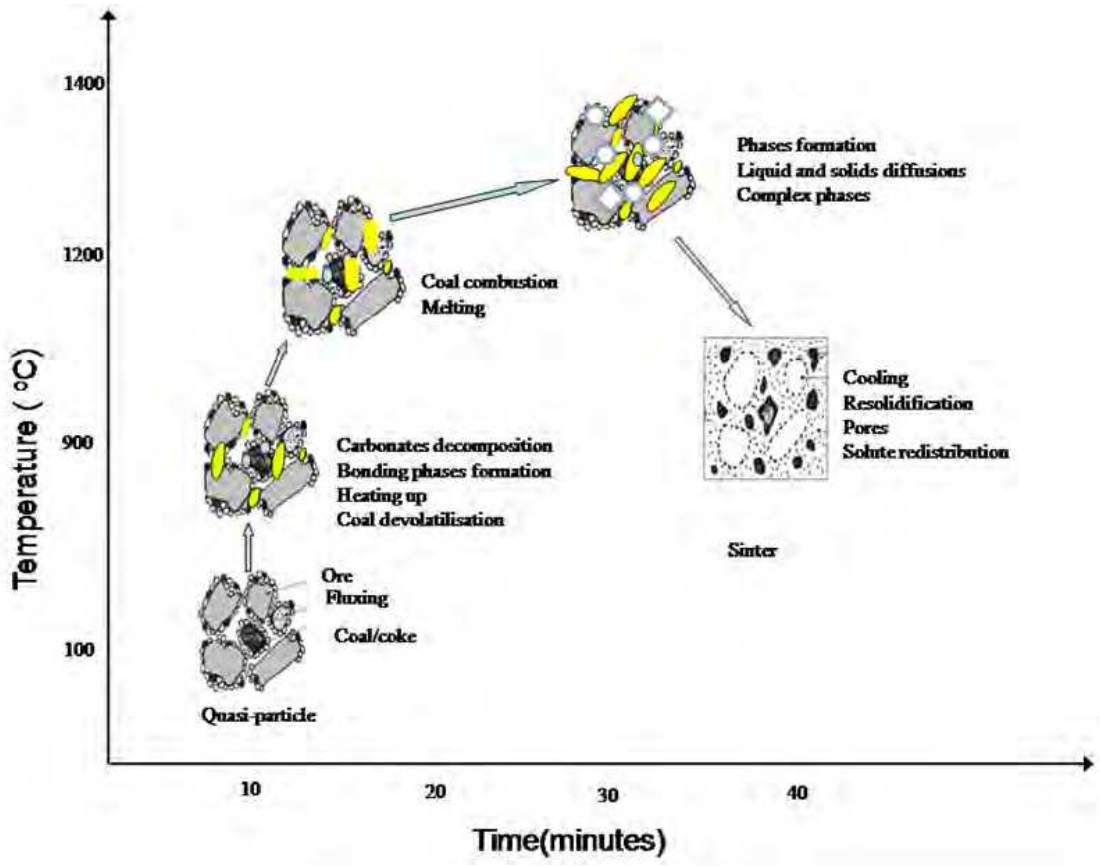

Fig. 2. Thermal cycle of the materials in the sinter strand.

Several attempts have been done to predict the final properties of the sinter product (Water et al. 1989, Kasai et al. 1989, 1991). The most important parameters are reducibility, degradability and the size distribution which influences strongly the sinter performance within the blast furnace. Waters and co-workers(Waters et al. 1989), developed a mathematical model to predict the final size distribution of the sinter product, however, as the authors pointed out, the model did not considered the kinetics of the sintering phenomena, which strongly affect the final size distribution, reducibility and degradation within the blast furnace. Kasai et al (Kasai et al. 1989, 1991) investigated the influence of the sinter structure into the macroscopic sinter properties. In their work a detailed explanation of the sintering mechanism and particles interaction is presented to clarify the bonding forces. The authors concluded that the void fraction and specific surface area are the main parameters influencing the sinter strength. They also concluded that the significant driving forces for structural changes in the sinter are compressive and capillary ones. Akiyama et al (Akiyama et al. 1992) investigated the heat transfer properties under the sinter bed conditions and established empirical correlations for the material conductivity. The mechanism of the oxidation and bonding phase formation in the sintering process conditions were studied by Yang et al (Yang et al. 1997). Yamaoka and Kawaguchi(Yamaoka \& Kawaguchi, 2005) discussed 3D variations on sinter properties produced on a pot apparatus experimental facility and presented a mathematical model based on transport 
phenomena to simulate the experimental conditions and draw some correlations to predict sinter properties based on model variables and measurements. However, there are few comprehensive mathematical models describing the sintering process in an industrial machine such as the usual Dwight-Lloyd process. Mitterlehner et al (Mitterlehner et al.,2004), presented a 1-D mathematical model of the sinter strand focusing on the speed of the sintering front. Cumming and Thurnlby and Nath et al(Cumming \& Thurnlby 1990 and Nath et al., 1996), developed a 2-D mathematical model based on transport equations, however, their analysis considered a few chemical reactions and the rate of phase transformations were simplified. Therefore, a comprehensive mathematical model able to describe the chemical reactions coupled with momentum, energy and species transport has yet to be considered. In the present work, a three dimensional mathematical model of the sinter strand is developed based on the multiphase multi-component concept and detailed interactions between the gas and solid phases are formulated: The main features of the model are as follows: a) dynamic interaction of the gas mixture with the solids; b) overall heat transfer of all phases which accounts for convection and radiation phenomena; c) kinetics of vaporization and condensation of water; d) decomposition of carbonates; e) reduction and oxidation of the iron bearing materials; f) coke combustion and gasification; g) volatile matter evolution; h) shrinkage of the packed bed; h) partial melt and resolidification of the solids and i) phase changes to form alumina-calcium- silicates. Figure 2 shows schematically a typical thermal cycle of the materials within the sinter strand and indicates main phenomena that occur along the sinter strand. In the present work, a comprehensive mathematical model to describe the phenomena within the sinter strand is presented. The present model differs significantly from the former ones due to the concept of multiple and coupled phenomena treatment, three -dimensional treatment of the sinter strand and detailed mechanism of chemical reactions involved in the process(Castro et al. 2005, Yamaoka et al 2005). The interphase interactions are considered via semi empirical sub-models for the momentum transfer, energy exchange due to chemical reactions, heat conduction, convection and radiation.

\section{Model features}

\subsection{Conservation equations}

In order to analyze the sintering process of an industrial strand machine, a multiphase, multi-component, three-dimensional mathematical model is proposed. The model considers the phases interacting simultaneously and the chemical species of each phase is calculated based on the chemical species conservation equations. The model concept and phase interactions are shown in Fig. 3. The model is based on conservation equations for mass, momentum energy(Austin et al. 1997, Castro et al. 2000, 2001, 2002, 2011) and mass fraction of chemical species of gas, solid phases: sinter feed, fine sinter(returned fine sinter), coke breeze(or other solid fuel), scales(fines of steel plant), fluxes and limestone. The liquid phase is composed of melted and formed components in the liquid phase. The re-solidified phase comprises the liquids re-solidified and phases formed during the re-solidification process. The final sinter cake will be formed by a mixture of these materials and its quality will depend upon the final compositions and volume fractions of each of these materials(Cores et al. 2010, Lv et al. 2009, Hayashi et al.2009). 


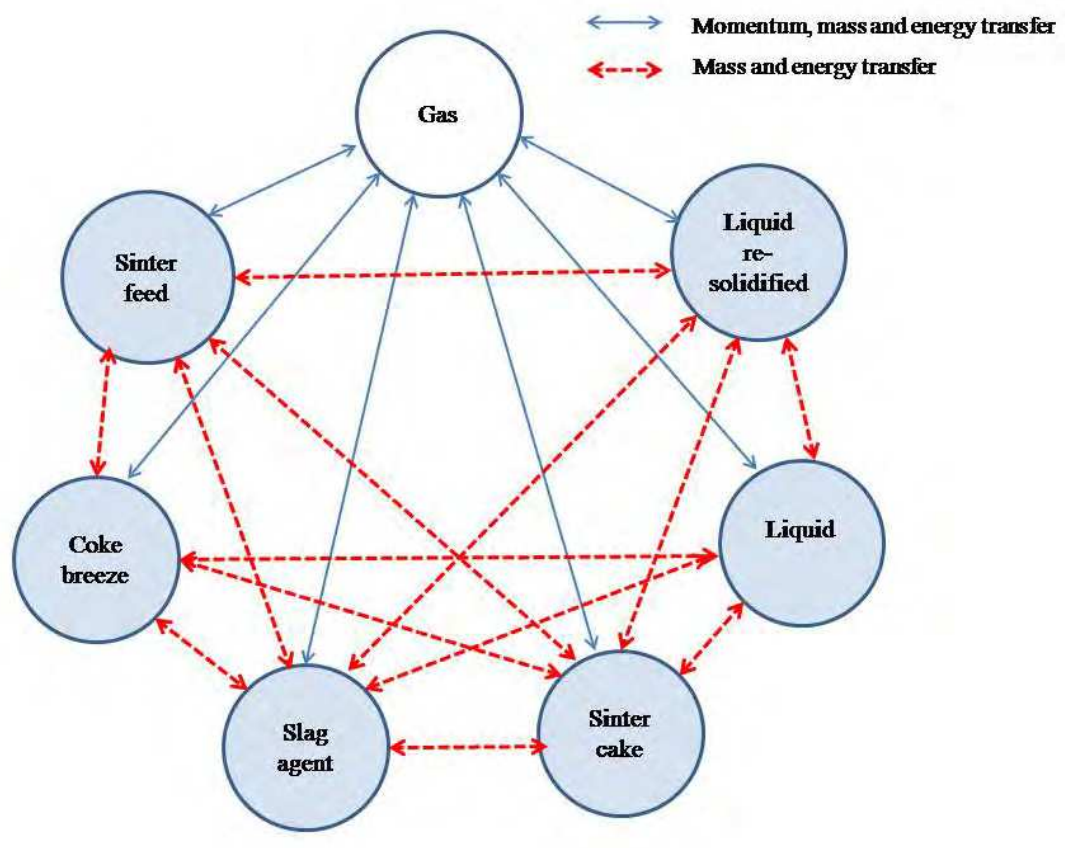

Fig. 3. Multiple phases considered in the present model.

In this model it is assumed that the liquid phase formed will move together with the remaining solid phase due to the viscosity, thus, equations for momentum transfer and enthalpy of the solids will account for this mixture of viscous liquid and solid materials. The equations for momentum, energy and chemical species are as follows:(Austin et al., 1997, Castro et al., 2000, 2001,2002, 2005).

Momentum:

$$
\frac{\partial\left(\rho_{i} \varepsilon_{i} u_{i, j}\right)}{\partial t}+\frac{\partial\left(\rho_{i} \varepsilon_{i} u_{i, k} u_{i, j}\right)}{\partial x_{k}}=\frac{\partial}{\partial x_{k}}\left(\mu_{i} \frac{\partial u_{i, j}}{\partial x_{k}}\right)-\frac{\partial P_{i}}{\partial x_{j}}-F_{j}^{i-l}
$$

Continuity:

$$
\frac{\partial\left(\rho_{i} \xi_{i}\right)}{\partial t}+\frac{\partial\left(\rho_{i} \xi_{i} u_{i, k}\right)}{\partial x_{k}}=\sum_{m=1}^{N r e a c t s} M_{n} r_{m}
$$

Enthalpy balance:

$$
\frac{\partial\left(\rho_{i} \varepsilon_{i} H_{i}\right)}{\partial t}+\frac{\partial\left(\rho_{i} \varepsilon_{i} u_{i, k} H_{i}\right)}{\partial x_{k}}=\frac{\partial}{\partial x_{k}}\left(\frac{k_{i}}{C_{p i}} \frac{\partial H_{i}}{\partial x_{k}}\right)+E^{i-l}+\sum_{m=1}^{\text {Nreacts }} \Delta H_{m} r_{m}
$$


The chemical species are individually considered within the phase, for gas, or components of the solid or liquid phases as presented in Eq. 4.:

$$
\frac{\partial\left(\rho_{i} \varepsilon_{i} \phi_{n}\right)}{\partial t}+\frac{\partial\left(\rho_{i} \varepsilon_{i} u_{i, k} \phi_{n}\right)}{\partial x_{k}}=\frac{\partial}{\partial x_{k}}\left(D_{n}^{e f f} \frac{\partial \phi_{n}}{\partial x_{k}}\right)+\sum_{m=1}^{N r e a c t s} M_{n} r_{m}
$$

\begin{tabular}{|c|c|c|c|}
\hline \multicolumn{4}{|c|}{ Equations of the gas phase } \\
\hline \multirow{3}{*}{ Gas } & Momentum & \multicolumn{2}{|c|}{$\mathrm{u}_{1, \mathrm{~g}}, \mathrm{u}_{2, \mathrm{~g}}, \mathrm{u}_{3, \mathrm{~g}}, \mathrm{P}_{\mathrm{g},}, \varepsilon_{\mathrm{g}}$} \\
\hline & Energy & \multicolumn{2}{|l|}{$\mathrm{h}_{\mathrm{g}}$} \\
\hline & $\begin{array}{l}\text { Chemical } \\
\text { Species }\end{array}$ & \multicolumn{2}{|c|}{$\mathrm{N}_{2}, \mathrm{O}_{2}, \mathrm{CO}, \mathrm{CO}_{2}, \mathrm{H}_{2} \mathrm{O}, \mathrm{H}_{2}, \mathrm{SiO}, \mathrm{SO}_{2}, \mathrm{CH}_{4}, \mathrm{C}_{2} \mathrm{H}_{6}, \mathrm{C}_{3} \mathrm{H}_{8}, \mathrm{C}_{4} \mathrm{H}_{10}$} \\
\hline \multicolumn{4}{|c|}{ Equations of the solid phase } \\
\hline \multirow{9}{*}{ Solid } & Momentum & \multicolumn{2}{|c|}{$\mathrm{u}_{1, \mathrm{~s}}, \mathrm{u}_{2, \mathrm{~s}}, \mathrm{u}_{3, \mathrm{~s}}, \mathrm{P}_{\mathrm{s}}, \varepsilon_{\mathrm{s}}$} \\
\hline & Energy & \multicolumn{2}{|l|}{$\mathrm{h}_{\mathrm{s}}$} \\
\hline & \multirow{7}{*}{$\begin{array}{l}\text { Chemical } \\
\text { Species }\end{array}$} & Fuels & $\begin{array}{l}\text { C,Volatiles, } \mathrm{H}_{2} \mathrm{O}, \mathrm{Al}_{2} \mathrm{O}_{3}, \mathrm{SiO}_{2}, \mathrm{MnO}, \mathrm{MgO}, \mathrm{CaO} \text {, } \\
\text { FeS, } \mathrm{P}_{2} \mathrm{O}_{5}, \mathrm{~K}_{2} \mathrm{O}, \mathrm{Na}_{2} \mathrm{O}, \mathrm{S}_{2}\end{array}$ \\
\hline & & Iron ore & $\begin{array}{l}\mathrm{Fe}_{2} \mathrm{O}_{3}, \mathrm{Fe}_{3} \mathrm{O}_{4}, \mathrm{FeO}, \mathrm{Fe}, \mathrm{H}_{2} \mathrm{O}, \mathrm{Al}_{2} \mathrm{O}_{3}, \mathrm{SiO}_{2}, \mathrm{MnO}, \\
\mathrm{MgO}, \mathrm{CaO}, \mathrm{FeS}, \mathrm{P}_{2} \mathrm{O}_{5}, \mathrm{~K}_{2} \mathrm{O}, \mathrm{Na}_{2} \mathrm{O}\end{array}$ \\
\hline & & $\begin{array}{l}\text { Return } \\
\text { Sinter (bed) }\end{array}$ & $\begin{array}{l}\mathrm{Fe}_{2} \mathrm{O}_{3}, \mathrm{Fe}_{3} \mathrm{O}_{4}, \mathrm{FeO}, \mathrm{Fe}, \mathrm{H}_{2} \mathrm{O}, \mathrm{Al}_{2} \mathrm{O}_{3}, \mathrm{SiO}_{2}, \mathrm{MnO}, \\
\mathrm{MgO}, \mathrm{CaO}, \mathrm{FeS}, \mathrm{P}_{2} \mathrm{O}_{5}, \mathrm{~K}_{2} \mathrm{O}, \mathrm{Na}_{2} \mathrm{O}, \mathrm{Ca}_{2} \mathrm{Fe}_{3} \mathrm{O}_{5}, \\
\mathrm{Al}_{2} \mathrm{MgO}_{4}\end{array}$ \\
\hline & & Scales & $\begin{array}{l}\text { C, Volatiles, } \mathrm{Fe}_{2} \mathrm{O}_{3}, \mathrm{Fe}_{3} \mathrm{O}_{4}, \mathrm{FeO}, \mathrm{Fe}, \mathrm{H}_{2} \mathrm{O}, \mathrm{Al}_{2} \mathrm{O}_{3} \text {, } \\
\mathrm{SiO}_{2}, \mathrm{MnO}, \mathrm{MgO}, \mathrm{CaO}, \mathrm{FeS}, \mathrm{P}_{2} \mathrm{O}_{5}, \mathrm{~K}_{2} \mathrm{O}, \mathrm{Na}_{2} \mathrm{O} \text {, } \\
\mathrm{Fe}_{2} \mathrm{Cl}_{6} \mathrm{H}_{12} \mathrm{O}_{6}, \mathrm{Ca}_{2} \mathrm{Fe}_{3} \mathrm{O}_{5}, \mathrm{Al}_{2} \mathrm{MgO}_{4}\end{array}$ \\
\hline & & $\begin{array}{l}\text { Fused } \\
\text { Materials }\end{array}$ & $\begin{array}{l}\mathrm{Fe}_{2} \mathrm{O}_{3}, \mathrm{Fe}_{3} \mathrm{O}_{4}, \mathrm{FeO}, \mathrm{Fe}, \mathrm{H}_{2} \mathrm{O}, \mathrm{Al}_{2} \mathrm{O}_{3}, \mathrm{SiO}_{2}, \mathrm{MnO}, \\
\mathrm{MgO}, \mathrm{CaO}, \mathrm{FeS}, \mathrm{P}_{2} \mathrm{O}_{5}, \mathrm{~K}_{2} \mathrm{O}, \mathrm{Na}_{2} \mathrm{O}, \mathrm{Ca}_{2} \mathrm{Fe}_{3} \mathrm{O}_{5}, \\
\mathrm{Al}_{2} \mathrm{MgO}_{4}\end{array}$ \\
\hline & & $\begin{array}{l}\text { Fluxing } \\
\text { agent }\end{array}$ & $\mathrm{CaO}, \mathrm{H}_{2} \mathrm{O}, \mathrm{Al}_{2} \mathrm{O}_{3}, \mathrm{SiO}_{2}, \mathrm{MnO}, \mathrm{MgO}, \mathrm{TiO}_{2}$ \\
\hline & & Sinter cake & $\begin{array}{l}\mathrm{Fe}_{2} \mathrm{O}_{3}, \mathrm{Fe}_{3} \mathrm{O}_{4}, \mathrm{FeO}, \mathrm{Fe}, \mathrm{H}_{2} \mathrm{O}, \mathrm{Al}_{2} \mathrm{O}_{3}, \mathrm{SiO}_{2}, \mathrm{MnO}, \\
\mathrm{MgO}, \mathrm{CaO}, \mathrm{FeS}, \mathrm{P}_{2} \mathrm{O}_{5}, \mathrm{~K}_{2} \mathrm{O}, \mathrm{Na}_{2} \mathrm{O}, \mathrm{Ca}_{2} \mathrm{Fe}_{3} \mathrm{O}_{5}, \\
\mathrm{Al}_{2} \mathrm{MgO}_{4}\end{array}$ \\
\hline
\end{tabular}

Table 1. Phases and chemical species considered in the model.

Where indexes $i$ and $l$ represent the phases, $j$ and $k$ are the indexes for coordinates component direction $n$ is chemical species and $m$ the indicator of the reactions, $M$ is the molecular weight of the species, $P$ is phase pressure, $F$ is component of momentum interactions among the phases and $r$ is the rate of chemical reactions. $\rho, \varepsilon, C p, k$ and $\Delta H$ are phase density, volume fractions, heat capacity, heat conductivity and heat due to chemical 
reactions, respectively. The quantity $E^{i-l}$ is the heat transfer among the phases and accounts for convective and radiation heat transfer. The gas -solids momentum interactions are represented by $F^{i-l}$ and detailed in the following section. The complete description and unit of these variable is presented in the list of variables and symbols. The chemical species for the solid and gas phases are presented in Table 1. Detailed chemical reactions and rate equations describing the in bed conditions of iron ore are found elsewhere(Austin et al., 1997, Castro et al., 2000, 2001,2002, 2005). Several authors have assessed particular phenomena and rate equations for interphase interactions and sintering process(Lv et. al., 2009, Kasai et. al, 2005, Jeon et al., 2010, Li et al.,2010, Nakano et al. 2005, 2009, 2010).

\subsection{Momentum and energy transfer}

The momentum transfer between the solid and gas are modeled based on the modified Ergun's equation as follows: (Castro et. al. 2005, Cumming et. al, 1990, Nath et al. 1997)

$$
\vec{F}_{g}^{s}=\sum_{m} f_{m}\left[1.75 \rho_{g}+\frac{150 \mu_{g}}{\left|\vec{U}_{g}-\vec{U}_{s}\right|}\left(\frac{v_{m}}{\left(1-v_{m}\right) d_{m} \varphi_{m}}\right)\right]\left(\frac{v_{m}}{\left(1-v_{m}\right) d_{m} \varphi_{m}}\right)\left(\vec{U}_{g}-\vec{U}_{s}\right)
$$

Where $f$ is the phase component volume fraction and $\mathrm{v}$ is the phase component bulk void fractions, $\mathrm{d}$ is the average diameter of the phase component and $\varphi$ is the shape factor ( $m=$ sinter feed, coke, limestone, mushy zone of liquid and solids, re-solidified and fines particles). $\vec{U}$ is the phase velocity vector, $\mu_{\mathrm{g}}$ is gas dynamic viscosity and $\rho_{\mathrm{g}}$ the gas density given by the ideal gas state relationship. Each of these components has its own particle diameter, porosity, shape factor and density. The overall heat transfer coefficient between the gas and solid phases is given by the Ranz-Marshall equation modified by Akiyama et al for moving beds and incorporated together with the interfacial area to give the overall heat transfer of solid to gas phase and vice-versa(Akiyama et al. 1993, Castro et al. 2000, Austin et al. 1997, Castro et al. 2002, 2005, Yamaoka et al. 2005)

$$
E^{g-s}=\sum_{m} f_{m} \frac{6\left(1-v_{m}\right)}{d_{m} \varphi_{m}} \frac{k_{g}}{\sum f_{m}\left(d_{m} \varphi_{m}\right)}\left[2+0.39\left(\operatorname{Re}_{g-s}\right)^{1 / 2}\left(\operatorname{Pr}_{g}\right)^{1 / 3}\right]\left(T_{g}-T_{s}\right)
$$

As shown in eq. 6, the gas-solid system inter-phase heat transfer is given by the product of the overall effective heat transfer coefficient, the interfacial area and the average temperature differences of the solid particles and gas phase. The average solids and gas temperatures used in Eq. 6 are calculated by solving eq. (7) for each phase, with the temperatures of each phase as incognita(Yamaoka et al. 2005, Castro et al. 2005, Nakano et al., 2010, Kamijo et al. 2009)

$$
h_{i}=\int_{n} \varepsilon_{i}\left(C_{p}\left(T_{i}\right) \phi\right)_{n} d T_{i}
$$

Where the quantities on the integral relation are averaged for each solid component and the component enthalpy is obtained by solving eq. 3, assuming that all solid and liquids 
components moves with the same velocity, although solid particles can assumes different temperatures depending on the heat exchanged with gas, chemical reactions and other particles.

\subsection{Calculations of phase properties}

The volume fractions occupied by each solid component are calculated based on empirical correlations solely dependent on the individual mean solid diameters as in eqs. 8 and 9.(Austin et al. 1997, Castro et al. 2005)

$$
\begin{gathered}
\varepsilon_{\text {coke }}=\left[0.153 \log \left(d_{\text {coke }}\right)+0.724\right] \\
\varepsilon_{m}=0.403\left[100 d_{m}\right]^{0.14} \quad(m=\text { sinter feed, sinter, fines, scales })
\end{gathered}
$$

The properties of the gas and solid phases are calculated considering the mixture rule based on the properties of the pure components. The density of the gas phase is calculated by using the ideal gas law.

$$
\rho_{\mathrm{g}}=\frac{P_{\mathrm{g}}}{R T_{\mathrm{g}}} \sum \phi_{j, \mathrm{~g}} M_{j}
$$

Where $\mathrm{j}$ stands for gas species. Pure component viscosities are calculated from statistical mechanical theories as follows:( Reid et al. 1988, Bird et al., 1960)

$$
\mu_{\mathrm{g}}=2.6693 \times 10^{-6} \frac{1}{\Omega_{\mu, j}} \sqrt{\frac{M_{j} T_{\mathrm{g}}}{\sigma_{j}}}
$$

With the parameters given by:

$$
\begin{gathered}
\Omega_{\mu, j}=\frac{1.16145}{\left(T^{*}\right)^{0.14874}}+\frac{0.52487}{\exp \left(0.77320 T^{*}\right)}+\frac{2.16178}{\exp \left(2.43787 T^{*}\right)} \\
T^{*}=\frac{k_{\text {Boltzmann }} T_{\mathrm{g}}}{\epsilon_{j}}
\end{gathered}
$$

Pure thermal conductivities are calculated using Eucken's polyatomic gas approximation (Wilke, 1950, Neufeld et al, 1972).

$$
k_{j}=M_{j}\left(C_{P, j}+\frac{5 R}{4 M_{j}}\right)
$$

The gas phase viscosity and thermal conductivity are calculated from pure components using Wilke's method (Wilke, 1950). 


$$
\begin{gathered}
\lambda_{\mathrm{g}}=\sum_{j \in \mathrm{g}}\left[\frac{\gamma_{j, \mathrm{~g}} \lambda_{j}}{\sum_{j j \in \mathrm{g}}\left(\gamma_{j j, \mathrm{~g}} \chi_{j, j \mathrm{j}}\right)}\right](\lambda=\mu, k) \\
\gamma_{j, \mathrm{~g}}=\frac{\left(\phi_{j, \mathrm{~g}} / M_{j}\right)}{\sum_{j j \in \mathrm{g}}\left(\phi_{j j, \mathrm{~g}} / M_{j}\right)} \\
\chi_{j, j j}=\left\{1+\left(\lambda_{j} / \lambda_{j j}\right)\left(M_{j j} / M_{j}\right)^{1 / 4}\right\}^{2}
\end{gathered}
$$

The binary diffusivity of the gas species is calculated by:

$$
D_{j, k}^{T}=0.0018583 \times 10^{-4} \frac{T^{1 / 2} \sqrt{\left(\frac{1}{M_{j}}\right)+\left(\frac{1}{M_{k}}\right)}}{\left(P_{\mathrm{g}} / 101325\right) \sigma_{\mathrm{ave}}^{2} \Omega_{\text {ave }}}
$$

And the parameters are calculated as follows:

$$
\begin{gathered}
\sigma_{\text {ave }}=0.5\left(\sigma_{j}+\sigma_{k}\right) \\
\Omega_{\text {ave }}=\frac{1.06036}{\left(T^{*}\right)^{0.15610}}+\frac{0.19300}{\exp \left(0.47635 T^{*}\right)}+\frac{1.03587}{\exp \left(1.5299 T^{*}\right)}+\frac{1.76474}{\exp \left(3.89411 T^{*}\right)} \\
T^{*}=\frac{k_{\text {Boltzmann }} T_{\mathrm{g}}}{\epsilon_{\text {ave }}} \\
\in_{\text {ave }}=\sqrt{\epsilon_{j} \epsilon_{k}}
\end{gathered}
$$

Where kboltzmann is the Boltzmann constant, $\sigma$ and $\in$ are characteristics constants of the colliding gas species(Reid et al. 1988, Bird et al., 1960). The gas temperature is defined by Eq. 23 as a function of gas enthalpy and composition.

$$
H_{\mathrm{g}}=\sum_{j \in \mathrm{g}} \phi_{j, \mathrm{~g}}\left[\Delta H_{j, \mathrm{~g}}^{298 K}+\int_{298 K}^{T_{\mathrm{g}}} C_{p, j}(T) d T\right]
$$

With

$$
C_{P, j}(T)=a_{j}+b_{j} T+c_{j} T^{-2}
$$


The solid properties are calculated based on the solid composition and the properties of the pure components. The pure component heat capacities are modeled by a polynomial function of the temperature as follows:

$$
\begin{gathered}
C_{P, k}=a_{k}+b_{k} T_{\mathrm{s}}+\frac{c_{k}}{T_{\mathrm{s}}^{2}} \\
C_{P, \mathrm{~s}}=\sum_{k \in \mathrm{s}} C_{P, k} \phi_{k, \mathrm{~s}} \\
H_{\mathrm{s}}=\sum_{k \in \mathrm{s}} \phi_{k}\left[\Delta H_{k}^{298 K}+\int_{298 K}^{T_{\mathrm{s}}} C_{P, k}(T) d T\right]
\end{gathered}
$$

The solid conductivity is modified to take into account the intra-bed radiation and boundary layer convection( Akiyama et al. 1992, Reid et al. 1988, Bird et al., 1960).

$$
k_{\mathrm{s}, \mathrm{eff}}=\left(1-\varepsilon_{\mathrm{s}}\right)\left(k_{\mathrm{g}}+a\right)+\varepsilon_{\mathrm{s}}\left[\frac{2}{3 k_{\mathrm{s}}}+\left(\frac{k_{\mathrm{g}}}{0.274}+b\right)^{-1}\right]^{-1}
$$

And the constants are given by:

$$
a=\alpha\left[1+\left(\frac{1-\varepsilon_{s}}{\varepsilon_{s}}\right)\left(\frac{1-e_{s}}{2 e_{s}}\right)\right]^{-1}
$$

Where es is the solid components emissivity, assumed 0.9 for iron bearing materials and 0.8 for coke breeze and anthracite throughout the calculations carried out in this study.

$$
\begin{gathered}
b=\alpha\left(\frac{e_{\mathrm{s}}}{2-e_{\mathrm{s}}}\right) \\
\alpha=0.1952 d_{\mathrm{s}}\left(\frac{T_{\mathrm{s}}}{100}\right)^{3}\left(\frac{4.184}{3600}\right)
\end{gathered}
$$

In the above equations the following nomenclature and Greek symbols are used:

A: surface area, $\left(\mathrm{m}^{2} \mathrm{~m}^{-3}\right)$

$C_{p}$ : heat capacity, $\left(\mathrm{J} \mathrm{kg}^{-1} \mathrm{~K}^{-1}\right)$

$d_{m}:$ solid component diameter, $(\mathrm{m})$

$d_{s}:$ solid phase mean diameter, $(\mathrm{m})$

$F_{g}^{s}$ : interaction force on solid phase due to gas phase, $\left(\mathrm{Nm}^{-3} \mathrm{~s}^{-1}\right)$

$f_{m}$ : solid component volume fraction $(\mathrm{m}=$ sinter feed, sinter return, limestone, fines, coke breeze, mushy and bonding phases), $\left(\mathrm{m}^{3} \mathrm{~m}^{-3}\right)$ 
$\mathrm{H}$ : enthalpy of the phase $\left(\mathrm{kJ} \mathrm{kg}^{-1}\right)$

$\vec{U}_{i}$ : phase velocity vector (i=gas and solid ), $\left(\mathrm{m} \mathrm{s}^{-1}\right)$

$\mathrm{P}$ : phase pressure $(\mathrm{Pa})$

$\operatorname{Pr}_{g}=\frac{C_{p, g} \mu_{g}}{k_{g}}:$ Prandtl number, (-)

$\operatorname{Re}_{g-s}=\frac{\rho_{g}\left|\vec{U}_{g}-\vec{U}_{s}\right|}{\mu_{g}} d_{s}:$ particle Reynolds number, (-)

$R$ : gas constant, $\left(\mathrm{J} \mathrm{mol}^{-1} \mathrm{~K}^{-1}\right)$

$S_{\phi}$ : source or sink terms for the $\phi$ variables, (various)

$\mathrm{x}_{\mathrm{i}}$ : spatial coordinates, $(\mathrm{m})$

t: time, (s)

$\mathrm{T}$ : temperature, $(\mathrm{K})$

$\phi_{i, k}$ : dependent variables in eq. 1 , (calculated by the model), [various]

$\varphi_{m}$ : solid diameter shape factor $(\mathrm{m}=$ sinter feed, sinter return, limestone, fines, coke, mushy and bonding), (-)

$v_{m}$ : porosity of solid component $\left(\mathrm{m}^{3} \mathrm{~m}^{-3}\right)$

$\rho_{i}$ : phase density (i= gas and solid), $\left(\mathrm{kg} \mathrm{m}^{-3}\right)$

$\mu$ : phase effective viscosity (Pa s)

$\varepsilon_{i}$ : phase volume fraction ( $i=$ gas and solid), $\left(\mathrm{m}^{3} \mathrm{~m}^{-3}\right)$

\subsection{Boundary and initial conditions}

The system of differential equations presented above are completed with their initial and boundary conditions. The computational domain is defined by the region of the sinter strand for the case of the industrial scale process simulation with the above equations solved for stationary conditions. When the pot test experiment is considered, the simulations are carried out for transient calculations with a cylindrical pot of $60 \mathrm{~cm}$ of diameter and the height is determined in order to account for the operational conditions which reproduce the similarity of permeability and gas flow within the packed bed with the industrial machine. Regarding to the boundary and initial conditions for the solid phases, the composition, initial and inlet particle diameters, charging particle and volume fractions distributions and moisture content are specified at the charging position of the strand. The outlet boundary condition for the solid phase is assumed fully developed flow and no sleep condition is assumed at the sinter strand. The other boundaries such as lateral and bed surface are assumed zero velocities components gradient. For the energy balance equations convective and radiation coefficients are assumed for each of these surfaces. The gas inlet and outlet flow rates are determined by the pressure drop specified for each wind box determined by the blower controls and it is calculated interactively by accounting simultaneously for the mass balance and pressure drop of each wind box. The gas inlet temperature is specified at the surface of the bed and the outlet temperature are calculate by using the integral relation given by eq.(7). 


\subsection{Numerical features}

The multiphase model is composed of a set of partial differential equations that can only be solved by numerical method due to their nonlinearities on the boundary, initial and source terms. In this work, the set of differential equations described above is discretised by using the finite volume method and the resulting algebraic equations are solved by the iterative procedure using the line by line method combined with the tri-diagonal matrix solver algorithm(Melaaen,1992, and Karki \& Patankar, 1988). In this paper, the numerical grid used to simulate the pot test uses $32 \times 8 \times 16=4096$ control volumes in cylindrical coordinate system while the industrial strand of the sinter machine was discretised based on the Cartesian coordinate system with $11 \times 140 \times 16=24640$ control volumes. The numerical convergence was accepted for tolerance of the order of $10^{-6}$ for the velocity and temperature fields, meanwhile, for the chemical species the overall mass balance was accepted less than $1 \%$ for all chemical species calculated.

\section{Results and discussions}

\subsection{Model validation}

The model constructed was validated by using the pot test results for reproducing an actual sinter operation of average $37100 \mathrm{~kg} \mathrm{~m}^{-2}$ per day of productivity. The gas temperatures and compositions were recorded by using thermocouples and chromatography analysis. The temperature measurements carried out were averaged and plotted for intervals of 3 minutes within the sinter bed at 50, 350 and $750 \mathrm{~mm}$, respectively, from the top to the bottom of the pot. The gas composition was measured at the outlet. The composition of the raw materials used for predicting both, pot experiments and industrial operations, is shown in Table 2. Figure 4 shows the comparison of temperature measurements and model predictions of the pot experiment representing an actual operation (a-c) and for gas recycling of $10 \%$ on the first 10 wind boxes and pre-combustion with natural gas using pilot burners (d-f). As can be observed, the calculated results presented very good agreement with the measured values. Actually, these cases of calculations were used as base cases for the calculations of the industrial operations conditions. Figure 5 shows vertical temperature profiles measured and predicted by the model at 5, 15 and 30 minutes, respectively. As can be seen in Fig 5 a-c the calculated results are also very close to the measured ones at the top, meddle and bottom of the pot reactor.

\begin{tabular}{|c|c|c|c|c|c|c|c|c|c|}
\hline & $\mathrm{C}$ & $\mathrm{VM}$ & $\mathrm{Fe}_{2} \mathrm{O}_{3}$ & $\mathrm{Fe}$ & $\mathrm{H}_{2} \mathrm{O}$ & $\mathrm{SiO}_{2}$ & $\mathrm{Al}_{2} \mathrm{O}_{3}$ & $\mathrm{MgO}$ & $\mathrm{CaO}$ \\
\hline $\begin{array}{c}\text { Iron ore } \\
(\%)\end{array}$ & - & - & 88.2 & - & 5.2 & 3.5 & 1.4 & 0.4 & 0.8 \\
\hline $\begin{array}{c}\text { Fuel } \\
(\%)\end{array}$ & 86.9 & 1.4 & - & - & 4.3 & 4.1 & 3.0 & 0.1 & 0.2 \\
\hline $\begin{array}{c}\text { Limestone } \\
\left(\begin{array}{c}\text { (Flux } \\
(\%)\end{array}\right.\end{array}$ & - & - & - & - & 0.8 & 2.2 & 1.6 & $\begin{array}{c}13 \\
\left(\mathrm{MgCO}_{3}\right)\end{array}$ & $\begin{array}{c}82 \\
\left(\mathrm{CaCO}_{3}\right)\end{array}$ \\
\hline $\begin{array}{c}\text { Scale } \\
(\%)\end{array}$ & 31.9 & 3.1 & 10.8 & 35.5 & 5.8 & 6.6 & 4.1 & 0.4 & 1.7 \\
\hline
\end{tabular}

Table 2. Chemical compositions of the raw materials used. 


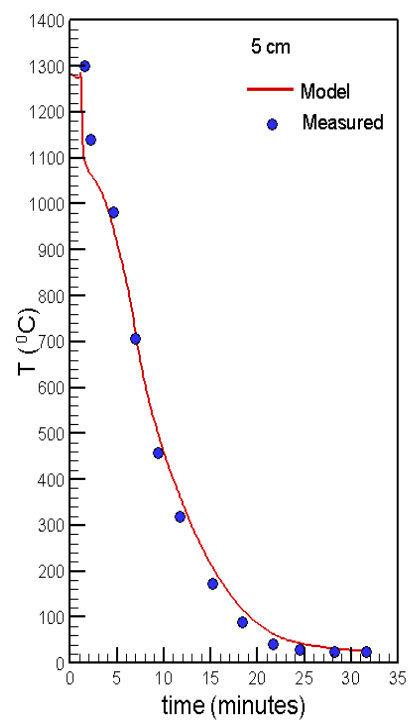

a) $5 \mathrm{~cm}$

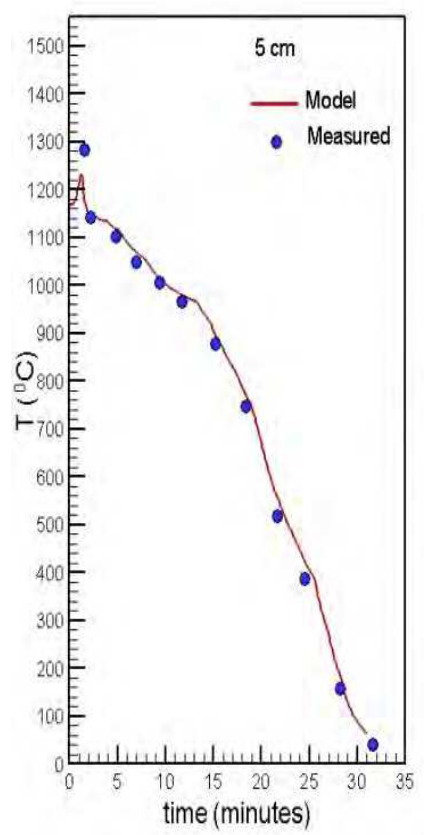

d) $5 \mathrm{~cm}$

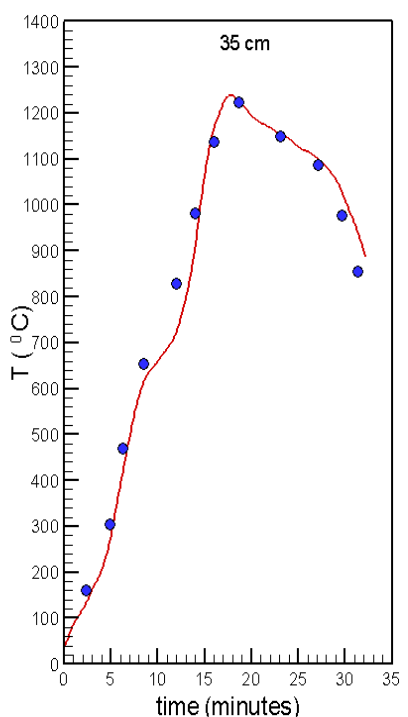

b) $35 \mathrm{~cm}$

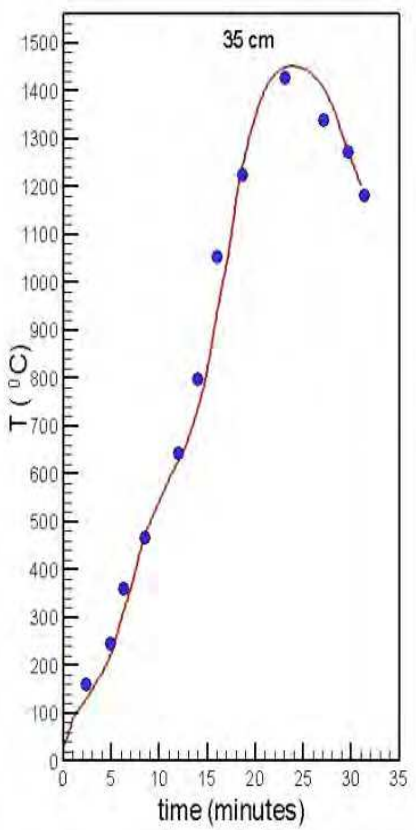

e) $35 \mathrm{~cm}$

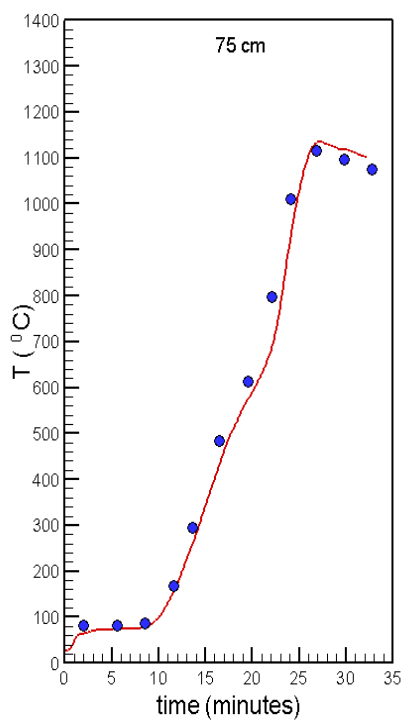

c) $75 \mathrm{~cm}$

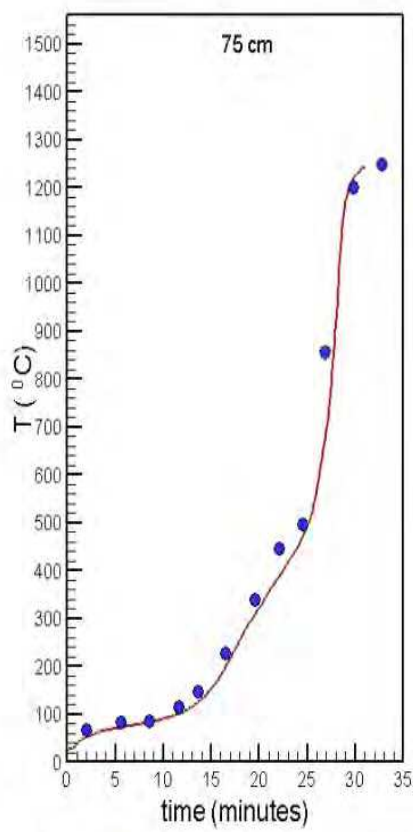

f) $75 \mathrm{~cm}$

Fig. 4. Comparison of temperature predictions and measurements for the pot test experiment (a-c: actual operation technique and d-f: gas recycling and pre combustion of natural gas). 

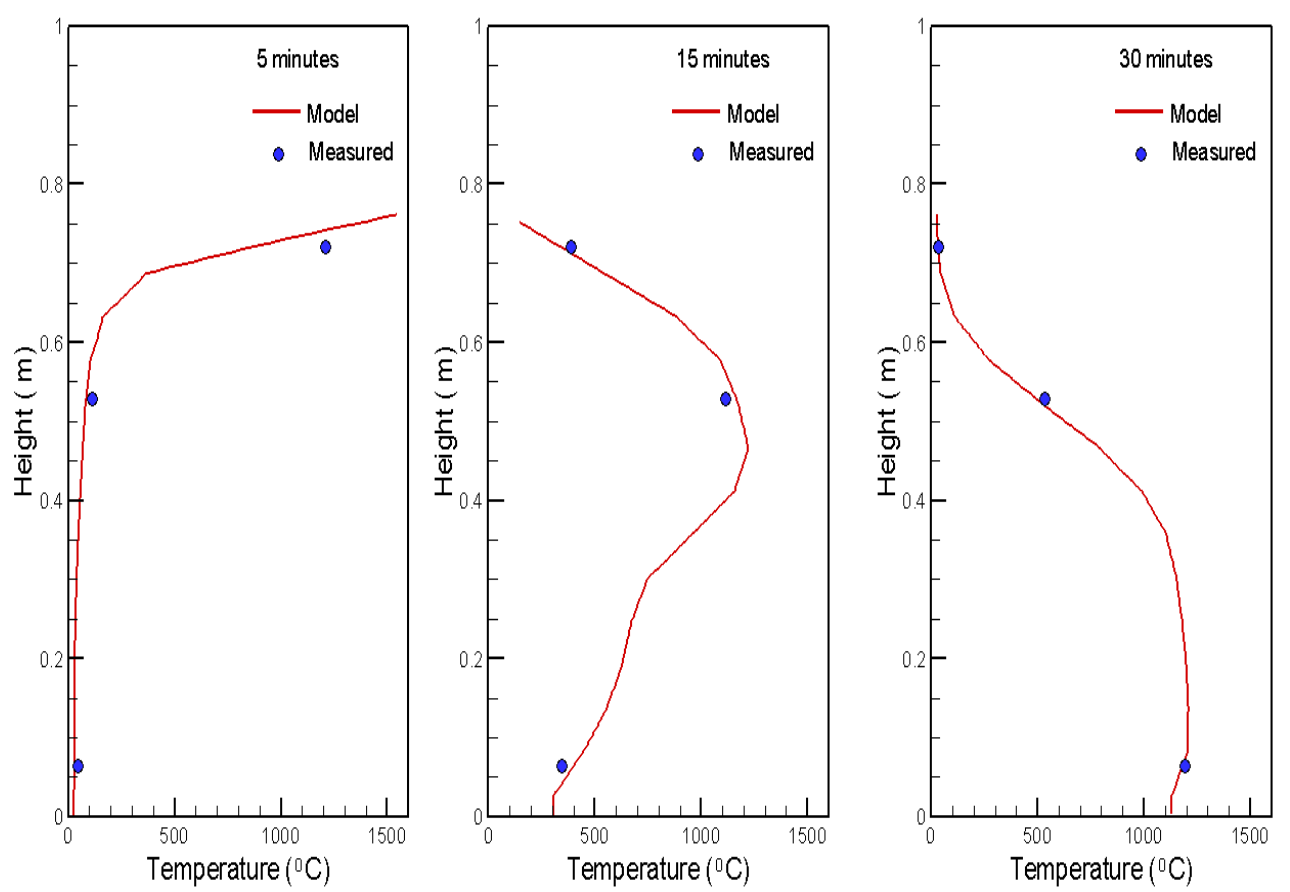

Fig. 5. Comparison of vertical temperature profiles within the pot experiment.

The measured and calculated temperatures used in Figure 5 for the sake of comparison were taken as the averaged solid and gas temperature predicted by the model and compared with the thermocouples measurements positioned in the interior of the packed bed. The reason for this approximation is due to the thermocouples are in direct contact with the gas and solid packed bed. In this comparisons it is assumed the local arithmetic average values. These results confirms the validity of the model to predict the thermal conditions within the sintering process. Therefore, in this investigation, it is assumed that the main sub-models to predict the heat transfer and chemical reactions are suitable to model the inner phenomena. Next step of the study was to apply the model to predict industrial sintering operation scenarios. The starting point was to apply the model to predict the actual operation of a typical machine and confirm the validation of the model into a industrial sinter machine. Thus, it was carried out a campaign of measurements in bed temperatures by inserting thermocouples within the sintering bed and recorded along the sinter strand until the sinter discharging position to the cooling system. Figure 6 shows industrial data predictions and measurements of temperature distributions along the sinter strand for a conventional operation of a large sinter machine. The measured values are obtained by averaging the recorded values passing through the control volume which represents the numerical values.

The model predictions for the temperature is also in excellent agreement with the measured ones, similarly as observed in previous cases of pot experiment validations. Therefore, it is assumed that the model is able to predict new operations techniques and draw newly 
scenarios using recycling outlet gas and increasing amount of inner residues such as scales and fines. In the following section these possibilities are considered.

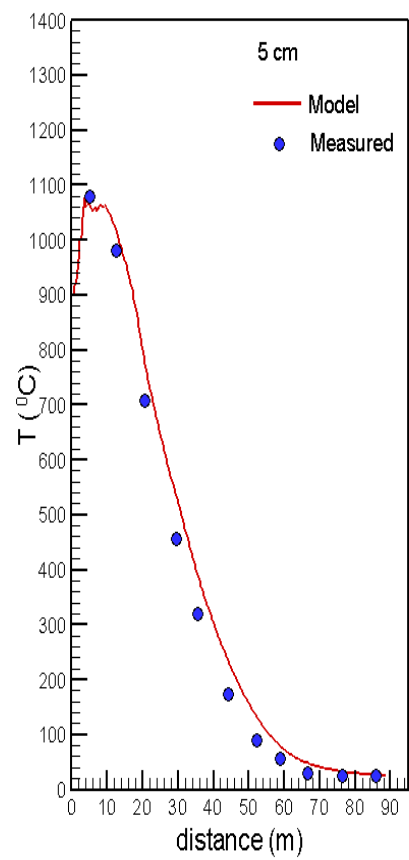

a) $5 \mathrm{~cm}$ from surface

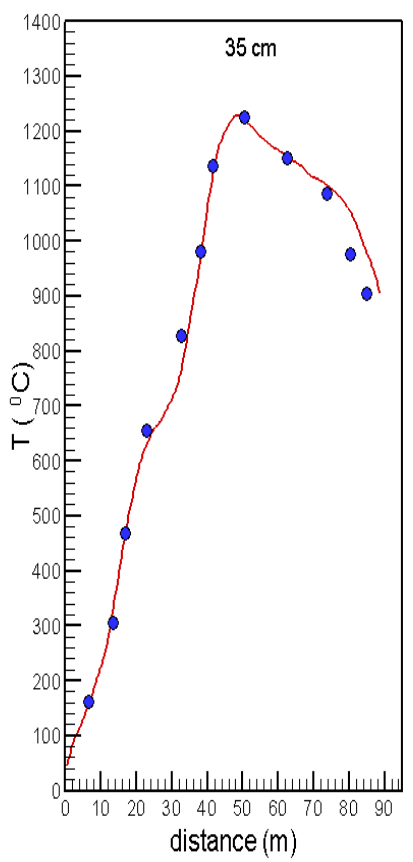

b) $35 \mathrm{~cm}$ from surface

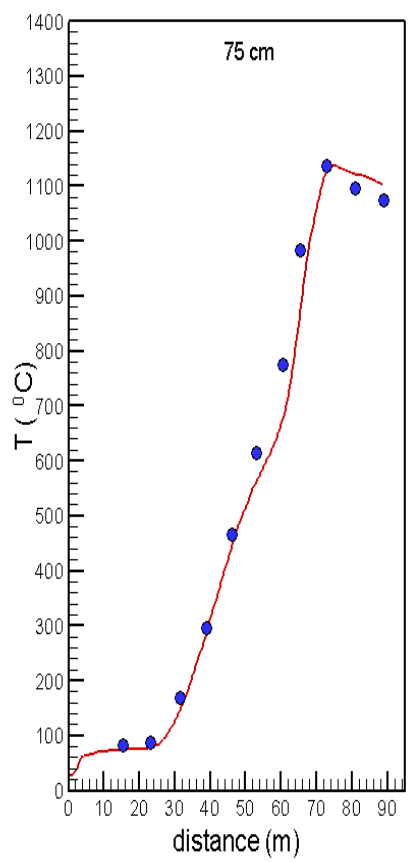

c) $75 \mathrm{~cm}$ from surface

Fig. 6. Industrial data predictions and measurements of temperature distributions along the sinter strand- conventional operation.

\subsection{Simulations of advanced operations techniques}

In this section, 8 operation scenarios for the iron ore sinter process are simulated and compared with the actual practice. A set of 4 cases of outlet gas recycling with precombustion of natural gas and another set of 4 cases of combined scenarios of increasing recycling of scales and outlet gas recycling are selected. Table 3 summarizes the operational results predicted by the model and the base case (actual operation). As can be seen, from cases 1-4 increasing amount of outlet gas recirculation is proposed and additional natural gas is used in a pre-combustion chamber to promote post combustion and increase the temperature. From cases 5-8, increasing amount of recycling scale is proposed and combined with gas recycling aiming at searching better combination of the both practices. In this study is concluded that case 6 showed better combination of high gas and scale reutilization with low fuel consumption. The di-calcium ferrite $\left(\mathrm{Ca}_{2} \mathrm{Fe}_{3} \mathrm{O}_{5}\right)$ formation in the final sinter product is of special interest for the technological application due to its strong effect on the reducibility and mechanical strength. 


\begin{tabular}{|c|c|c|c|c|c|c|c|c|c|}
\hline & Conve & \multicolumn{4}{|c|}{ Recycling gas only } & \multicolumn{4}{|c|}{ Recycling gas and scale } \\
\hline & Base & Case 1 & Case 2 & Case 3 & Case 4 & Case 5 & Case 6 & Case 7 & Case 8 \\
\hline $\begin{array}{l}\text { Productivity } \\
\left(\mathrm{t} \mathrm{m}^{-2} \text { day }^{-1}\right)\end{array}$ & 37.1 & 40.5 & 41.3 & 42.7 & 46.3 & 47.4 & 46.3 & 45.9 & 46.5 \\
\hline $\begin{array}{l}\text { Bed height } \\
(\mathrm{mm})\end{array}$ & 770 & 820 & 840 & 860 & 900 & 900 & 900 & 900 & 900 \\
\hline $\begin{array}{l}\text { Basicity } \\
\left(\frac{\mathrm{CaO}}{\mathrm{SiO}_{2}}\right)\end{array}$ & 1.87 & 1.72 & 1.81 & 1.82 & 1.84 & 1.54 & 1.75 & 1.54 & 1.38 \\
\hline$\left(\frac{\mathrm{CaO}+\mathrm{MgO}}{\mathrm{SiO}_{2}+\mathrm{Al}_{2} \mathrm{O}_{3}}\right)$ & 1.41 & 1.32 & 1.37 & 1.38 & 1.41 & 1.12 & 1.35 & 1.22 & 1.04 \\
\hline $\begin{array}{l}\text { Fuel rate } \\
\left(\mathrm{kg} \mathrm{t}^{-1}\right) \\
(\%)\end{array}$ & $\begin{array}{l}49.6 \\
5\end{array}$ & $\begin{array}{l}49.3 \\
5\end{array}$ & $\begin{array}{l}40.4 \\
4\end{array}$ & $\begin{array}{l}39.3 \\
3.9\end{array}$ & $\begin{array}{l}39.3 \\
4\end{array}$ & $\begin{array}{l}32.7 \\
3.8\end{array}$ & $\begin{array}{l}37.8 \\
3.8\end{array}$ & $\begin{array}{l}34.5 \\
3.5\end{array}$ & $\begin{array}{l}34.5 \\
3.5\end{array}$ \\
\hline $\begin{array}{c}\text { Iron ore } \\
(\%)\end{array}$ & 56 & 56 & 55.2 & 55.3 & 55.4 & 54.1 & 53.5 & 51.8 & 55.9 \\
\hline $\begin{array}{c}\text { Sinter return } \\
(\%)\end{array}$ & 28.8 & 28.7 & 31 & 31.1 & 30.9 & 30.3 & 28.8 & 29.3 & 23.1 \\
\hline $\begin{array}{c}\text { Scale } \\
(\%)\end{array}$ & 0.0 & 0.0 & 0.0 & 0.0 & 0.0 & 2.1 & 4.3 & 6.1 & 8.2 \\
\hline $\begin{array}{l}\text { Limestone } \\
(\%)\end{array}$ & 10.2 & 10.3 & 9.8 & 9.7 & 9.7 & 9.7 & 9.6 & 9.3 & 9.3 \\
\hline $\begin{array}{c}\mathrm{Ca}_{2} \mathrm{Fe}_{3} \mathrm{O}_{5} \\
(\%)\end{array}$ & 28.4 & 24.8 & 26.2 & 26.2 & 26.1 & 22.6 & 25.3 & 23.1 & 20.4 \\
\hline $\begin{array}{c}\text { Exhaust gas } \\
\left(\mathrm{Nm}^{3} \mathrm{t}^{-1}\right)\end{array}$ & 706 & 683.9 & 634.9 & 613.5 & 639.3 & 660.5 & 666.8 & 691.2 & 694.8 \\
\hline $\begin{array}{c}\text { Recycling gas } \\
(\%)\end{array}$ & 0.0 & 5.6 & 6.5 & 10.4 & 13.7 & 13.2 & 13.3 & 12.9 & 12.7 \\
\hline $\begin{array}{c}\text { Additional Fuel } \\
\left(\mathrm{CH}_{4}\right) \\
\left(\mathrm{kg} \mathrm{t}^{-1}\right)\end{array}$ & 0.0 & 4.5 & 6.8 & 7.3 & 7.8 & 4.2 & 4.7 & 5.3 & 5.8 \\
\hline $\begin{array}{l}\text { PCDD/F } \\
\text { Emissions } \\
\left(\mathrm{ng} \mathrm{Nm}^{-3}\right)\end{array}$ & 1.9 & 2.3 & 2.6 & 2.7 & 2.5 & 2.2 & 1.9 & 2.0 & 2.1 \\
\hline
\end{tabular}

Table 3. Operational parameters for simulated scenarios.

Next, the inner temperature fields are compared for selected cases. It is worth to mention that feasible distributions profiles were obtained for all scenarios, however only cases 6 and 8 are shown due to their attractive operational parameters, better performance and higher 
re-utilization methods. The temperature distributions within the sinter strand are shown in Fig. 7 for actual sintering machine operation and the case of higher scale recycling combined with gas and pre-combustion(case 8). As can be seen in Fig. 7(b) the sintering temperature was not uniformly obtained in the sinter strand, and therefore, this operation could lead to produce sinter of lower mechanical strength.
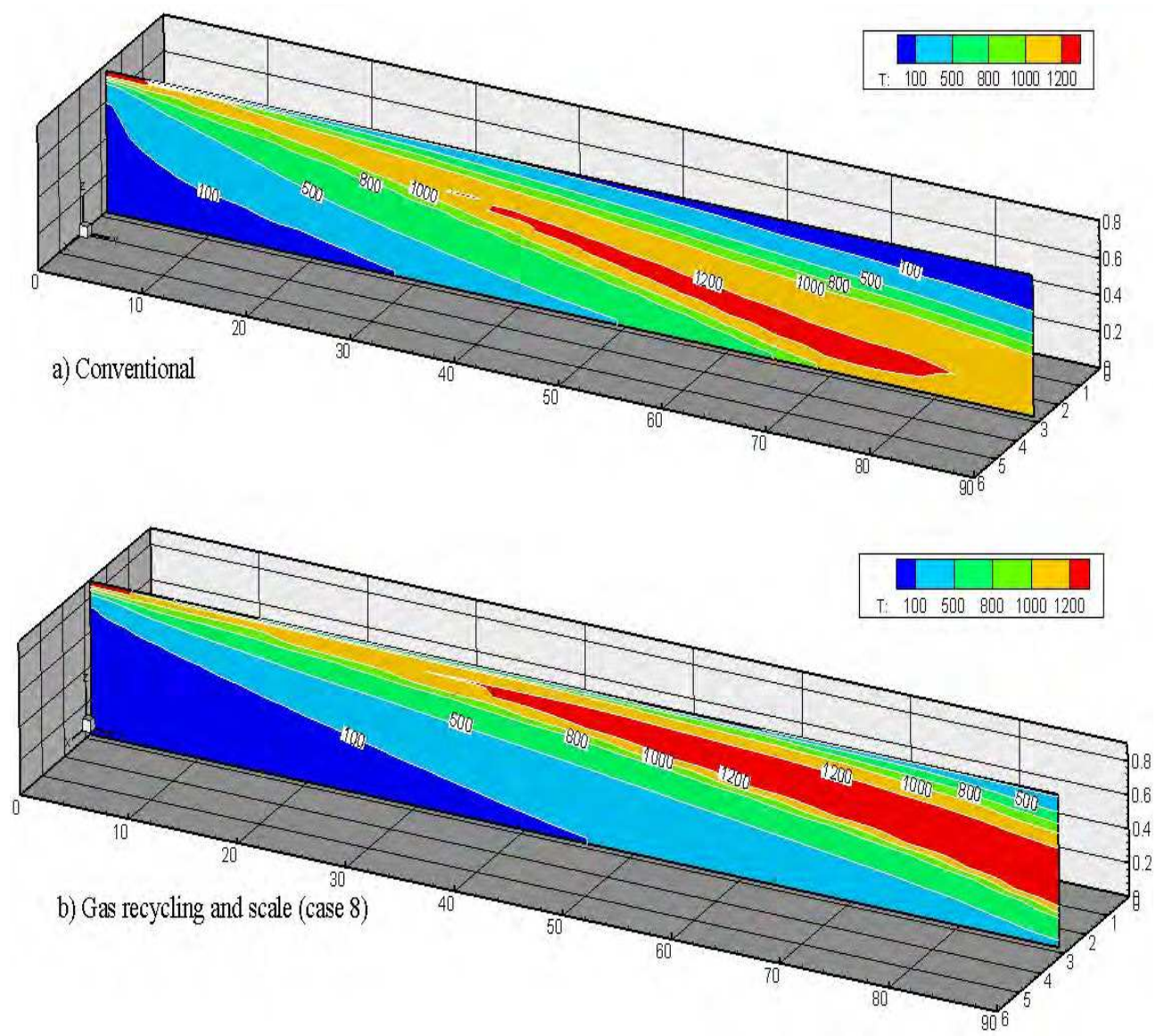

Fig. 7. Comparison between the sinter bed temperature distributions for conventional and high gas and scale recycling methods.

Figure 8 shows a comparison of the inner temperature predictions of the actual operation with the optimum scenario for gas and scale recycling. As observed, the high temperature region is enlarged and the residence time within the sintering zone is higher. Although all the scenarios presented in Table 2 could be considered operational, case 6 was selected due to good temperature distribution combined with overall operational parameters. 

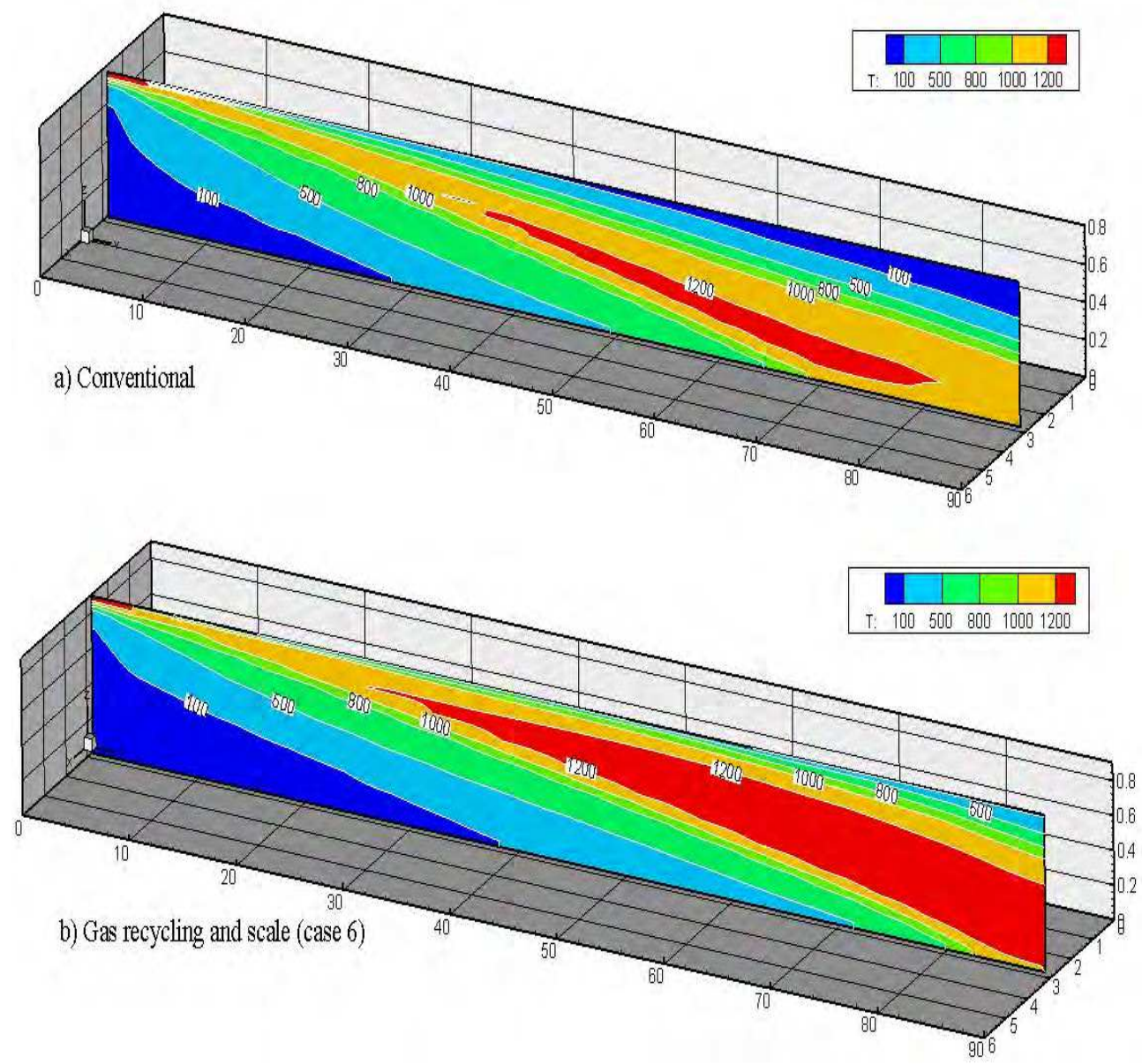

Fig. 8. Optimized sinter bed temperature distributions for recycling methods in comparison with conventional one.

Therefore, the calculation results was used to indicate promising operational conditions able to give higher productivity combined with low fuel consumption and high recycling amount of outlet gas and powder residues such as scale and others. Finally, this scenario was compared with the actual operation with regard to the emissions of dioxin (PCDD- Poly Chlorinated Di-benzene Dioxin) and furans(PCDF - Poly Chlorinated Di-benzene Furan). The sintering process have been strongly requested to reduce polychlorinated substances emissions, therefore, new technologies need to be compared not only from the point of view of economics but also from the environmental load (Castro et al. 2005, Cieplik et al. 2003, Kasai et al. 2008, Nakano et al. 2005, 2009). Figure 9 and 10 show the comparisons of PCDD and PCDF distributions within the sinter strand for actual operation and case 6 . Although the concentration distributions are slightly higher when the recirculation methods of scale 
and outlet gas is considered, when outlet gas re-utilization is adopted the PCDD and PCDF are also recycled into the higher temperature zone and partially decomposed and depending on the gas recirculation method the total amount could be reduced. As observed in Table 2, when the recycling amount is considered the specific emissions are reduced.
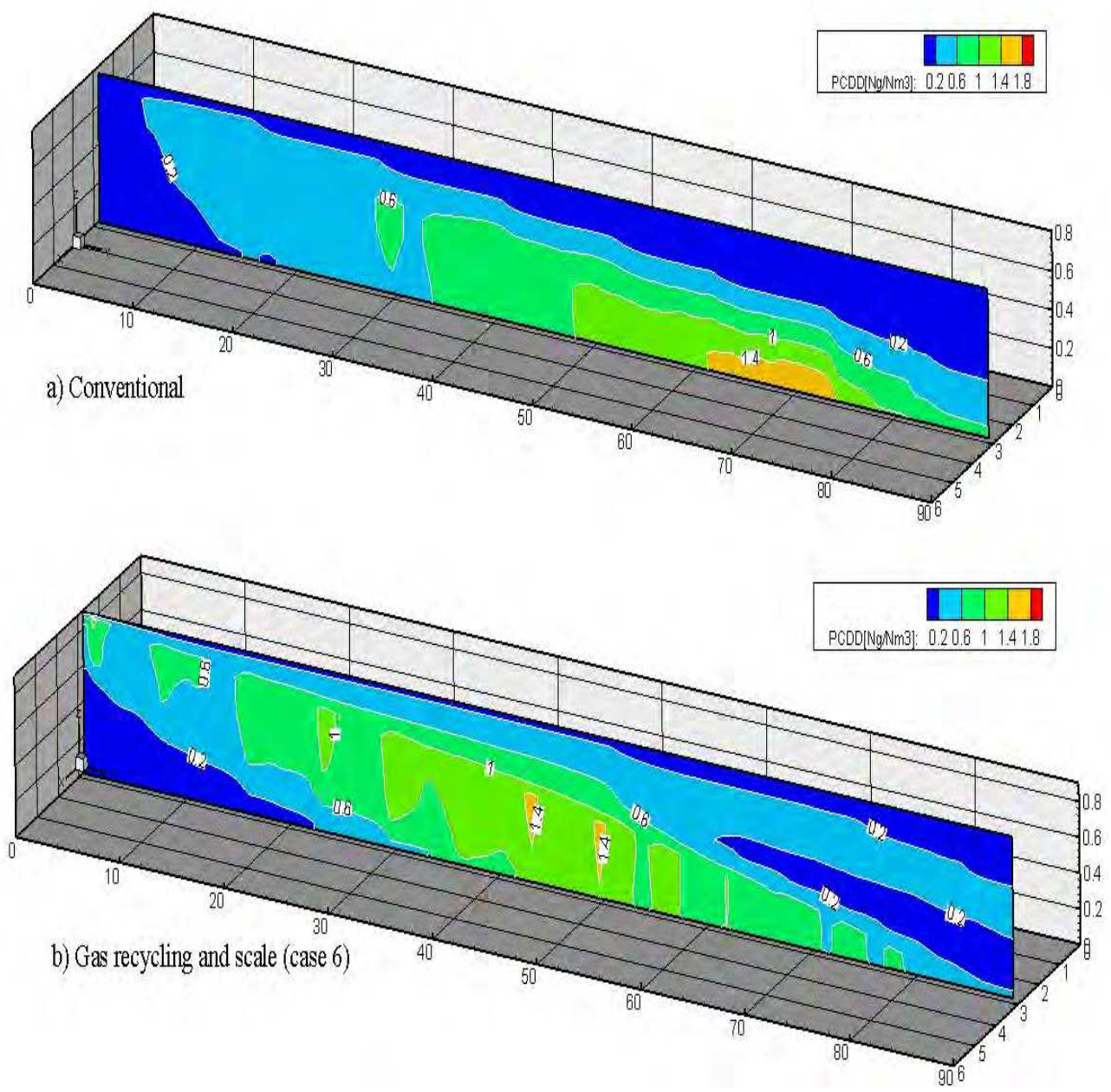

Fig. 9. Predictions of PCDD distributions within the sinter bed. 

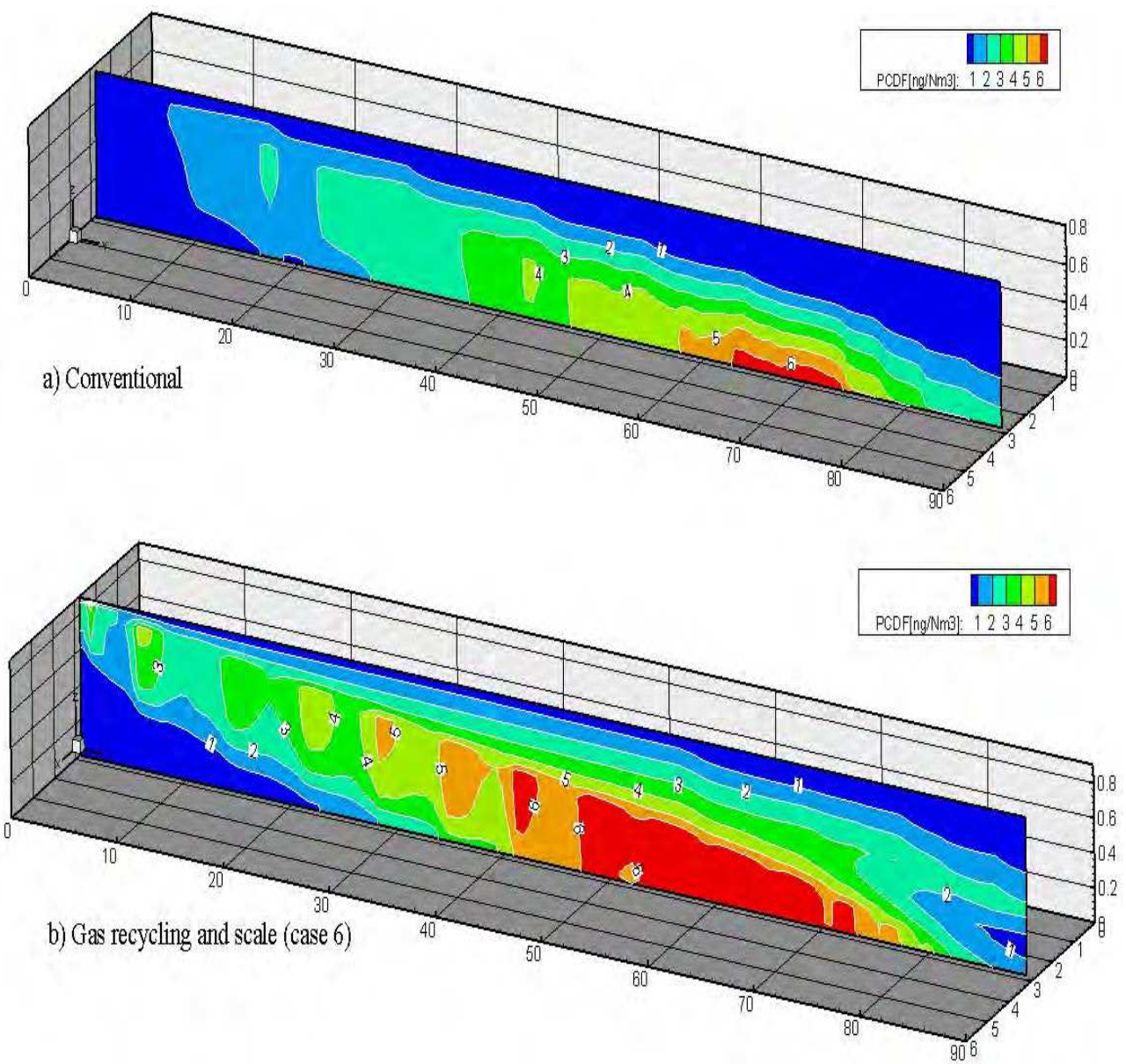

Fig. 10. Predictions of PCDF distributions within the sinter bed. 


\section{Conclusions}

In this chapter a mathematical model of the sintering process of a steel works has been derived in order to predict optimum scenarios of fines and gas recycling. The model is based on transport equations of momentum, energy and chemical species coupled with chemical reactions and phase transformations. The model predicted the temperature distributions inside the sintering bed together with the final sinter composition. The model was validated against the measured values for pot experiments and industrial monitoring temperature distributions. For all validation cases considered in this study the model predictions closely agreed with the measured values. Finally, the model was used to predict advanced operations such as high amount of scale recycling combined with outlet gas recirculation and pre-combustion of auxiliary fuels. The model developed in this study has shown potential applications to search for new technologies and point out advantages when compared with actual operation techniques. The model showed potential applications in order to monitoring industrial sintering machines and develop high efficiency operational techniques from the point of view of environment load and economical aspects.

\section{Acknowledgment}

This work was partially supported by CNPq - Conselho Nacional de Desenvolvimento Científico e Tecnológico and Faperj - Fundação Carlos Chagas Filho de Amparo a Pesquisa do Estado do Rio de Janeiro - Brazil.

\section{References}

Akiyama, T. Hohta, H., Takahashi, R., Waseda, Y. and Yagi, J.,(1992), Measurement and modeling of thermal conductivity for dense iron oxide and porous iron ore agglomerates in stepwise reduction. ISIJ International, vol. 32, No. 7, (July, 1992), pp. 829-837. ISSN 0915-1559

Aizawa, T. and Suwa, Y..,(2005), Meso-porous modeling for theoretical analysis of sinter ores by the phase-field, unit cell method. ISIJ International, vol. 45, No. 4, (April 2005), pp. 587-593. ISSN 0915-1559

Austin, P.R., Nogami, H. and Yagi, J. (1997), A mathematical model for blast furnace reaction analysis based on the four fluid model. ISIJ International, vol. 37, No. 8, (August, 1997), pp. 748-755. ISSN 0915-1559

Castro, J. A, Nogami, H. and Yagi, J. ,(2000), Transient Mathematical Model of Blast Furnace Based on Multi-fluid Concept, with Application to High PCI Operation. ISIJ International, vol. 40, No. 7, (July, 2000), pp. 637-646. ISSN 0915-1559

Castro, J. A , Nogami, H. and Yagi, J.,(2001), Numerical Analysis of Multiple Injection of Pulverized Coal, Prereduced lron Ore and Flux with Oxygen Enrichment to the Blast Furnace ISIJ International, vol. 41, No.1, (January, 2001), pp. 18-24. ISSN 09151559

Castro, J.A. Nogami, H. and Yagi, J., (2002), Three-dimensional Multiphase Mathematical Modeling of the Blast Furnace Based on the Multifluid Model. ISIJ International, vol. 42, No. 1, ( January, 2002), pp. 44-52. ISSN 0915-1559 
Castro, J. A., Silva, A.J., Nogami, H. and Yagi, J., (2004), Simulação computacional da injeção de carvão pulverizado nas ventaneiras de mini altos-fornos Tecnologia em Metalurgia e Materiais, Vol. 1, No. 2, (October, 2004), pp.59-62, ISSN 2176-1515

Castro, J. A., Silva, A.J., Nogami, H. and Yagi, J., (2005), modelo matemático tridimensional multi-fásico da geração de dioxinas no leito de sinterização. Tecnologia em Metalurgia e Materiais, Vol. 2, No. 1, (July, 2005), pp.45-49, ISSN 2176-1515

Castro, J. A., Silva, A.J., Sasaki, Y. and Yagi, J., (2011), A Six-phases 3-D Model to Study Simultaneous Injection of High Rates of Pulverized Coal and Charcoal into the Blast Furnace with Oxygen Enrichment. ISIJ International, vol. 51, No. 5, (May,2011), pp. 748-758. ISSN 0915-1559

Cieplik, K. M., Carbonell, J. P., Munoz, C., Baker, S., Kruger, S., Liljelind, P., Marklund, S. and Louw, R.,(2003), On dioxin formation in iron ore sintering. Environment Science Technology, vol. 37, No 15, (June, 2003), pp. 3323-3331,ISSN 101021

Cores, A., Babich, A. Muniz, M., Ferreira, S. and Mochon, J. (2010), The influence of different iron ores mixtures composition on the quality of sinter. ISIJ International, vol. 50, No. 8 , (August, 2010), pp.1089-1098. ISSN 0915-1559

Cumming, M.J. and Thurlby, J. A: (1990), Developments in modeling and simulation of iron ore sintering, Ironmaking and Steelmaking, vol. 17, No. 4, (April, 1990), pp. 245254, ISSN 0301-9233

Jeon, Ji-Won, Jung, Sung-Mo and SASAKI, Y., (2010), Formation of Calcium Ferrites under Controlled Oxygen Potentials at 1273 K. ISIJ International, vol. 50, No 8, (August 2010), pp. 1064-1070, ISSN 0915-1559

Kamijo, C., Matsumura, M. and Kawaguchi, T.(2009), Production of carbon included sinter and evaluation of its reactivity in blast furnace environment. ISIJ International, vol. 49, No. 10, (October, 2009), pp. 1498-1504. ISSN 0915-1559

Karki, K. C. and S. V. Patankar, S. V. (1988), Calculation Procedure for Viscous Incompressible Flows in. Complex Geometries. Numer. Heat Transfer, B, vol. 14, pp. 295-307, ISSN: 1040-7790

Kasai, E., Rankin, W.J., . Lovel, R.R and Omori,Y.,(1989), An analysis of the structure of iron ore sinter cake, ISIJ International, vol. 29, No. 8, (August, 1989), pp. 635-641. ISSN 0915-1559

Kasai, E., Batcaihan, B., Omori, Y., Sakamoto, N. and Kumasaka, A.,(1991), Permeation characteristics and void structure of iron ore sinter cake. ISIJ International, vol. 31, No. 11, ( November, 1991), pp. 1286-1291. ISSN 0915-1559

Kasai, E, Komarov, S., Nushiro, K. and Nakano, M., (2005), Design of bed structure aiming the control of void structure formed in the sinter cake. ISIJ International, vol. 45, No. 4,(April 2005), pp.538-543, ISSN 0915-1559

Kasai, E. Kuzuhara, S., Goto, H. and Murakami, T., (2008), Reduction in dioxin emission by the addition of urea as aqueous solution to high-temperature combustion gas. ISIJ International, vol. 48, No. 9 (September, 2008), pp. 1305-1310. ISSN 0915-1559

Hayashi, N. Komarov, S. V. and Kasai, E. (2009), Heat transfer analysis of mosaic embedding iron ore sinter (MEBIOS) process. ISIJ International, vol. 49, No. 5, (May 2009), pp.681-686, ISSN 0915-1559 
Li, L., Liu, J., Wu, X., Ren, X., BING, W. and Wu, L. (2010). Influence of Al2O3 on Equilibrium Sinter Phase in N2 Atmosphere. ISIJ International, vol. 50, No 2, (February, 2010), pp. 327-329. ISSN 0915-1559

Lv. X., Bai, C., Qiu, G., Zhang, S. and Shi, R, (2009), A novel method for quantifying the composition of mineralogical phase in iron ore sinter, ISIJ International, vol. 49, No. 5, ( May, 2009), pp. 703-708. ISSN 0915-1559

Melaaen. M.C. (1992), Calculations of fluid flows with staggered and nonstaggered curvilinear nonorthogonal grids - The theory. Numerical Heat Transfer, B, vol. 21, No.1. (January, 1992), pp. 1-19, ISSN: 1040-7790

Mitterlehner, J. , Loeffler, G., Winter, F. Hofbauer, H., Smid, H., Zwittag, E. , Buergler, T.H., Palmer, O. and Stiasni, H.,(2004), Modeling and Simulation of Heat Front Propagation in the Iron Ore Sintering Process ISIJ International, vol. 44, No. 1, (January, 2004), pp. 11-20. ISSN 0915-1559

Nakano, M., Morii, K. and Sato, T. (2009), Factors accelerating dioxin emission from iron ore sintering machines. ISIJ International, vol. 49, No. 5, (May, 2009) , pp.729-734. ISSN 0915-1559

Nakano, M., Hosotani, Y. and Kasai, E., (2005), observation of behavior of dioxins and some reating elements in iron ore sintering bed by quenching pot test. ISIJ International, 2005, vol. 45, No.4, (April, 2005), pp. 609-617. ISSN 0915-1559

Nakano, M., Katayama, K. and Kasama, S. (2010), Theoretical characterization of steadystate heat wave propagating in iron ore sintering bed. ISIJ International, vol. 50, No. 7, pp.1054-1058. ISSN 0915-1559

Nath, N. K. Silva, A.J. and Chakraborti, N., (1997), Dynamic Process Modeling of Iron Ore Sintering. Steel Research, vol. 68, No.7, (July, 1997), pp. 285-292, ISSN 1611-3683

Neufeld, P.D., Janzen, A.R. and Aziz, R.A. (1972), Empirical equations to calculate the transport collision integrals for Lennard-Jones potentials. Journal Chemical Physics, vol. 57, No. 3, pp.1100-1102, ISSN 0021-9606

Umekage, T. and Yuu, S., (2009), Numerical simulation of Particle agglomeration and bed shrink in sintering process. ISIJ International, vol. 49, No. 5, (May, 2009) , pp. 693702. ISSN 0915-1559

Waters, A.G., Lister, J.D. and Nicol, S.K, (1989), A Mathematical Model for the Prediction of Granule Size Distribution for Multicomponent Sinter Feed. ISIJ International, vol.29, No. 4, (April, 1989), pp. 274-283. ISSN 0915-1559

Yamaoka, H and Kawaguchi, T, (2005). Development of a 3-D sinter process mathematical simulation model. ISIJ International, vol. 45, No.4,(April 2005), pp. 522-531. ISSN 0915-1559

Yang, L. X. and Matthews, E., (1997), Sintering reactions of magnetite concentrates under various atmospheres. ISIJ International, vol. 37, No. 11, (November, 1997), pp. 10571065. ISSN 0915-1559

Bird, R.B., Stewart, W.E. and Linghtfoot ,E.N, (1960), Transport Phenomena, Wiley Int. New York.

R.C.Reid, J.M.Prausnitz and B.E.Poling: (1988), The properties of Gases and Liquids, 4th Ed., McGraw-Hill, New York. 
Wilke, C.R.. (1950), A viscosity equation of gas mixtures. Journal Chemical Physics, vol.18, pp. 517-519, ISSN 0021-9606 


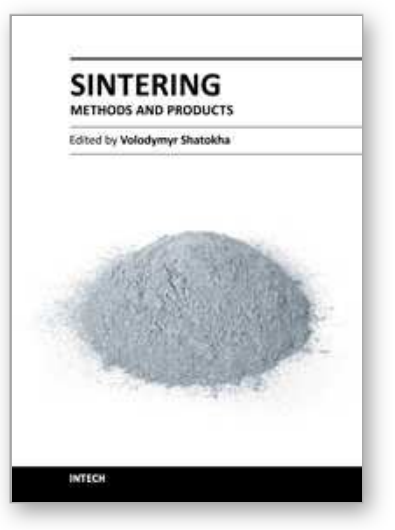

\author{
Sintering - Methods and Products \\ Edited by Dr. Volodymyr Shatokha
}

ISBN 978-953-51-0371-4

Hard cover, 316 pages

Publisher InTech

Published online 23, March, 2012

Published in print edition March, 2012

This book is addressed to a large and multidisciplinary audience of researchers and students dealing with or interested in sintering. Though commonly known as a method for production of objects from fines or powders, sintering is a very complex physicochemical phenomenon. It is complex because it involves a number of phenomena exhibiting themselves in various heterogeneous material systems, in a wide temperature range, and in different physical states. It is multidisciplinary research area because understanding of sintering requires a broad knowledge - from solid state physics and fluid dynamics to thermodynamics and kinetics of chemical reactions. Finally, sintering is not only a phenomenon. As a material processing method, sintering embraces the wide group of technologies used to obtain such different products as for example iron ore agglomerate and luminescent powders. As a matter of fact, this publication is a rare opportunity to connect the researchers involved in different domains of sintering in a single book.

\title{
How to reference
}

In order to correctly reference this scholarly work, feel free to copy and paste the following:

Jose Adilson de Castro (2012). Modeling Sintering Process of Iron Ore, Sintering - Methods and Products, Dr. Volodymyr Shatokha (Ed.), ISBN: 978-953-51-0371-4, InTech, Available from:

http://www.intechopen.com/books/sintering-methods-and-products/modeling-sintering-process-of-iron-ore

\section{INTECH}

open science | open minds

\author{
InTech Europe \\ University Campus STeP Ri \\ Slavka Krautzeka 83/A \\ 51000 Rijeka, Croatia \\ Phone: +385 (51) 770447 \\ Fax: +385 (51) 686166 \\ www.intechopen.com
}

\author{
InTech China \\ Unit 405, Office Block, Hotel Equatorial Shanghai \\ No.65, Yan An Road (West), Shanghai, 200040, China \\ 中国上海市延安西路65号上海国际贵都大饭店办公楼405单元 \\ Phone: +86-21-62489820 \\ Fax: +86-21-62489821
}


(C) 2012 The Author(s). Licensee IntechOpen. This is an open access article distributed under the terms of the Creative Commons Attribution 3.0 License, which permits unrestricted use, distribution, and reproduction in any medium, provided the original work is properly cited. 